\title{
Introduction to the law of economic and monetary union
}

Economic and monetary union (EMU) is without doubt one of the most revolutionary achievements in the history of European integration. The goals it pursues are shared by all Member States: economic stability, balanced economic growth, high employment levels, and sustainable public finances. Nonetheless, it found itself at the centre (but importantly, was not the main cause) of a serious sovereign debt crisis that brought the European Union (EU) to the verge of collapse, fuelled political parties and movements whose identities were (and still are) built around an anti-Europe sentiment, and brought European integration to a standstill for over a decade.

EMU thus became part of the political and economic debate during those years of crisis in a way that had never happened before. Discussions made their way from the innermost rooms of European central banks and institutions to the front pages and television studios - with many of the most critical technical, legal and economic aspects being trivialised along the way. What is more, the clashes - even on a purely legal level - were extremely heated. EU institutions' compliance with EMU's framework was the subject of some judgments issued by the Court of Justice of the European Union (CJEU), which even led to an almost unprecedented clash with the German Federal Constitutional Court. And numerous national courts issued decisions striking down measures adopted by EU Member States during the crisis years, in agreement with EU institutions, on the grounds that they infringed on constitutionally protected fundamental rights. All of this was only added ammunition for those who firmly opposed the fiscal rules that euro-area Member States were expected to adhere to.

In short, EMU became the preferred scapegoat of many, whose fight against it was often based on political and ideological prejudice rather than on well-reasoned, technically sound arguments. As a matter of fact, the inner workings and mechanisms of EMU were not always clear to its detractors. EMU's legal framework certainly showed its limitations during those ten difficult years following the financial crisis of 2007, but the debate at the time neglected to consider EMU's structural flaws, let alone possible remedies for them. Rather, the focus was on what measures could be immediately adopted to address the various problems that continued to emerge. And as will be seen 
in the pages that follow, this led to swings of the pendulum over those years in search of solutions: be it rigidity versus flexibility, political decisions versus rigorous enforcement of the rules, or the Community method versus the intergovernmental method.

Though it is perhaps too soon to say with any certainty, EMU could very well be the point from which European integration restarts. Indeed, the Covid-19 epidemic has sparked a reaction that - if lessons have been learnt from the mistakes made during the sovereign debt crisis - could, in due course, lead to the much-desired (but always postponed) deepening of EMU. This step is the sine qua non of continuing with European integration: i.e., completing the internal market, establishing an autonomous fiscal capacity for the EU with adequate resources, reforming EU institutions to bring citizens and institutions closer, rethinking some policies, and so on. A Europe that is exposed to periodic risks of economic and financial crises, that is divided between frugal countries demanding rigorous fiscal policies and countries seeking growth through expansionary fiscal policies, that is required to follow somewhat outdated fiscal rules containing no appropriate mechanisms to prevent or remedy crises, is a Europe that will struggle to fulfil its role in an increasingly divided, conflictual world.

The aim of this book is to bridge at least some of the knowledge gaps that, up to now, have characterised the debate on EMU's functioning. To understand the current situation - and above all, the prospects for change - it is important to first understand how EMU came to be and, even more importantly, how it has developed. However, this cannot be limited to a theoretical study of sources, laws and case law: in this case, it is crucial to combine a knowledge of "law in books" (not only EU law but also international law, and in some cases the constitutional law of Member States) with that of "law in action". To this effect, it is equally important to learn about the Member States' economic policies (including their social repercussions) and understand the impact of the monetary policy measures taken by the European Central Bank (ECB), to cite but a few examples.

This book thus aims to allow readers not only to familiarise themselves with EMU and delve into its mechanisms, but also to follow its development over time, see it in practice during the crisis years, understand the reactions to it, and learn about the prospects for its reform. Naturally, this is an introduction to the subject matter: though it strives to be as comprehensive as possible, it is by its very nature limited in scope. The idea is to provide readers with a succinct account of all the elements (and references to the vast number of regulatory sources) needed to allow them to further explore aspects of interest by seeking out specialist works. Readers will note that the chapters do not follow a strict chronological order but rather a logical one described in more detail below. Naturally, one could very well have a different opinion on the decision to 
include certain topics and exclude others. To cite one example, this book mentions the Banking Union and the Capital Markets Union - which, though not part of EMU, are in many respects complementary to it - but does not examine these broad-ranging initiatives in depth.

This work is divided into three parts, which can be summed up as follows: (1) EMU's history and regulatory framework; (2) the European sovereign debt crisis; and (3) prospects for EMU reform. The first part opens with a historical overview starting from the late 1960s; it then goes on to examine EMU's initial regulatory framework and subsequent evolution over a period of more than 20 years. It concludes with an explanation of the measures taken by the ECB to combat the financial crisis. In general, the first part looks at the crisis through the eyes of EU institutions faced with a rapidly evolving situation that was certainly unforeseen (and perhaps even unforeseeable) when EMU was first conceived. The solutions proposed in response were often improvised and mostly designed to address the "here and now" - yet over time they became structural in nature. The second part examines how the sovereign debt crisis developed from the Member States' perspective. It thus begins by looking at their respective economic/financial situations in the years leading up to the crisis, followed by an analysis of the economic policies they adopted during the crisis, the impact of those policies, the reactions that ensued, and the debates over possible withdrawal from the euro area. Lastly, the third part analyses the many reforms proposed in recent years, which have been accelerated due to the general economic downturn brought on by the Covid-19 pandemic.

More in detail, the book begins with the history of European economic and monetary integration, which precedes the Maastricht Treaty by about 25 years and adoption of the single currency by about 30 years (Chapter 1). Looking back at the old debates, one realises that some of the issues discussed but not dealt with along the original path towards EMU have come up again in more recent times - and continue to hamper effective economic and monetary union. Nothing new under the sun.

Once a general framework of primary law is established (from the Maastricht Treaty onwards), the book shifts the focus to the Stability and Growth Pact (SGP): the set of rules designed to ensure Member States maintain fiscal discipline even after adopting the euro (Chapter 2). The SGP is perhaps the most controversial and hotly debated topic of recent years. Indeed, it has been the subject of heavy criticism, and its several amendments over the years have made it increasingly rigid. Furthermore, the fiscal discipline imposed on Member States has come to include rules addressing macroeconomic imbalances, and a series of very detailed measures have been put in place that require Member States to coordinate their respective economic policies more closely. Notably, these reforms have taken place not only within the framework of EU law (i.e., through the Community method) but also through 
the intergovernmental method. This was the case with the Treaty on Stability, Coordination and Governance (TSCG), also known as the Fiscal Compact, which in 2012 introduced more stringent provisions into the SGP (Chapter 3).

EMU's regulatory background is completed by examining the financial assistance mechanisms originally envisaged under the Treaty establishing the European Community (TEC) along with those introduced specifically to deal with the sovereign debt crisis (Chapter 4). The first part concludes with an analysis of the many measures adopted by the ECB during the crisis, which were considered "non-standard" because they fell outside the realm of the ECB's typical monetary policy instruments (Chapter 5). Without a doubt, the ECB played a key role in that difficult time, but by doing so it knowingly exposed itself to harsh criticism on the part of Member States and national central banks. Indeed, it was accused of acting outside the scope of its mandate and going beyond its prerogatives under the EU Treaties. This led to several cases reaching the CJEU, which in turn gave rise to strong clashes with the German Federal Constitutional Court - clashes that took on an unusually confrontational tone and are destined to leave their mark.

The second part of the book starts off with a brief examination of how crisis came to strike the five Member States that ended up requesting financial assistance from the EU (Greece, Ireland, Portugal, Spain and Cyprus), how each country's crisis developed, and what measures each took to fight it (Chapter 6). The chapter that follows focuses on Italy, which has never requested financial assistance but has been subject to an excessive deficit procedure (EDP) on two occasions. Italy has long been in a difficult situation due to its imposing government debt-to-GDP ratio, which is the second highest in Europe and one of the highest in the world (Chapter 7). For this reason, it has often been on the verge of a crisis that, given the importance of its economy, could have serious repercussions for the entire euro area.

The Member States hit hardest by the sovereign debt crisis put severe austerity policies in place to bring their government accounts under control - the book's second part thus concludes by analysing the reactions to these policies (Chapter 8). Their effects on employment and welfare led to great social unrest, which was only partially addressed by national constitutional courts through rulings that, in the name of fundamental rights, put restrictions on some of the more extreme austerity measures. One side effect of all this was the spread of a strong anti-Europe sentiment across the continent, with increasing calls for Member States to take back full control of their economic policies. And that only fuelled the arguments of those pushing for a possible withdrawal from the euro area (Chapter 9).

The last part of the book delves into the many ambitious reform proposals put forward by EU institutions and Member States in recent years, which for the most part have remained on paper (Chapter 10). However, the Covid-19 
pandemic appears to have changed everything: for the first time, Member States (which often stopped the reform process over fears of having to bear the costs) realised that this crisis is a matter of common concern. No country can save itself on its own. The massive collective effort to face the pandemic thus appears to herald a new era for Europe (Chapter 11). But it will be hard to make any real progress without first understanding how Europe made it to this point and what still needs to be done to secure the construction of EMU - an intrinsic part of the common European home. 
Alberto Saravalle - 9781800883000 Downloaded from PubFactory at 04/26/2023 12:06:34PM via free access 